\title{
Linkage to the CCM2 Locus and Genetic Heterogeneity in Familial Cerebral Cavernous Malformation
}

\author{
Nicolas Dupré, Dominique J. Verlaan, Collette K. Hand, Sandra B. Laurent, \\ Gustavo Turecki, W. Jeptha Davenport, Nicola Acciarri, Johannes Dichgans, \\ Akio Ohkuma, Adrian M. Siegel, Guy A. Rouleau
}

\begin{abstract}
Background: Cerebral cavernous malformation (CCM) is a form of intracranial vascular disease that may arise sporadically or be dominantly inherited. Linkage studies have revealed genetic heterogeneity among the dominantly inherited forms suggesting the existence of at least three loci called CCM1, CCM2 and CCM3. Methods: In the present study, we screened five families with dominantly inherited CCM for CCM1 gene mutations with denaturing high performance liquid chromatography (DHPLC). Then, we performed linkage analysis and haplotyping on these five families using highly polymorphic markers at the candidate CCM loci. Results: None of the five families tested with DHPLC were found to have mutations in the CCM1 gene. Based on haplotyping, we identified three families segregating alleles for CCM2, while two families segregated alleles for CCM3. Using linkage analysis, we could confirm that one family (IFCAS-1) had a positive Lod score of 2.03 ( $\mathrm{p}<0.0001)$ at the CCM2 locus using marker D7S678. Conclusions: The present study is the first one to replicate linkage at the CCM2 locus and provides a fifth family identified as such. It also supports the concept of genetic heterogeneity in CCM, identifying four other families that showed no mutations in the CCM1 gene.
\end{abstract}

\begin{abstract}
RÉSUMÉ: Liaison au locus CCM2 et hétérogénéité dans les CCM familiales. Contexte: La malformation caverneuse cérébrale $(\mathrm{CCM})$ est une forme de maladie vasculaire intracrânienne qui survient de façon sporadique mais qui peut aussi avoir un mode d'hérédité dominant. Des analyses de liaison ont montré une hétérogénéité génétique parmi les formes dont l'hérédité est dominante, suggérant l'existence d'au moins trois locus, CCM1, CCM2 et CCM3. Méthodes: Dans cette étude, nous avons évalué cinq familles présentant une CCM à hérédité dominante pour déterminer la présence de mutations dans le gène CCM1 au moyen de la chromatographie en phase liquide à haute performance dénaturante. Nous avons ensuite procédé à une analyse de liaison et à un haplotypage dans ces cinq familles au moyen de marqueurs très polymorphes des gènes candidats CCM. Résultats: Aucune mutation dans le gène CCM1 n'a été démontrée dans les cinq familles étudiées au moyen de marqueurs très polymorphes. Nous avons identifié par haplotypage trois familles où il y a ségrégation d'allèles de CCM2 avec la maladie et deux familles où il y a ségrégation d'allèles de CCM3 avec la maladie. Nous avons confirmé au moyen de l'analyse de liaison, qu'une famille avait un Lod score positif de 2,03 (p<0,0001) au locus CCM2 en utilisant le marqueur D7S678. Conclusions: Cette étude est la première à reproduire une liaison au locus CCM2 et identifie une cinquième famille dans laquelle la maladie est liée à ce gène. Elle supporte également le concept d'une hétérogénéité génétique dans la CCM en identifiant quatre autres familles où on n'a pas décelé de mutation dans le gène CCM1.
\end{abstract}

Can. J. Neurol. Sci. 2003; 30: 122-128

Cerebral cavernous malformation (CCM; OMIM 116860) is a dominantly inherited form of intracranial vascular disease with a prevalence of up to $0.5 \%$ in the general population. ${ }^{1,2} \mathrm{~A}$ proportion of patients affected by these lesions become symptomatic, presenting usually between 20 and 40 years of age with intracranial hemorrhage, focal neurological deficits or seizures. Patients can be managed either conservatively or treated with surgical resection when lesions cause recurrent hemorrhage or seizures., ${ }^{3,4}$ Little is known about the
From the Center for Research in Neurosciences, Montreal General Hospital (DJV,CKH, SBL) and Department of Neurology and Neurosurgery (ND, WJD, GAR), McGill University, Montreal, Quebec, Canada; Douglas Hospital Research Institute, Department of Psychiatry, McGill University, Verdun, Quebec (GT), Canada; Neurosurgical Department, Bellaria Hospital, Via Altura, Italy (NA); Department of Neurology, University of Tübingen , Tübingen, Germany (JD); Department of Neurosurgery, Gifu Prefectural Hospital, Gifu City, Japan (AO); Epilepsy Program, Department of Neurology, University Hospital Zürich, Zürich, Switzerland (AMS). ReCEIVED May 15, 2002. ACCEPTED IN FINAL FORM OCtOBER 22, 2002. Reprint requests to: Nicolas Dupré, Center for Research in Neurosciences, Montreal General Hospital and Department of Neurology and Neurosurgery, McGill University, 1650 Cedar Ave., Montreal, Quebec, H3G 1A4 Canada 
pathophysiology of these lesions which have very characteristic features on magnetic resonance imaging (MRI), and are described pathologically as dilated sinusoidal vascular spaces surrounded by a collagenous matrix devoid of mature vessel elements. ${ }^{5,6}$

Both autosomal dominantly inherited and sporadic forms of the disease are recognized. ${ }^{7}$ Among Hispanic Americans with CCM, there is evidence of a founder mutation in the CCM1 gene (chr. 7q21-q22) that accounts for almost all familial cases. ${ }^{8}$ In non-Hispanic kindreds, however, while some support linkage to CCM1, families have been described for which linkage to this locus is excluded.9,10 Multilocus linkage on non-Hispanic kindreds has revealed linkage to two additional loci referred to as CCM2 (chr. 7p15-13) and CCM3 (chr. 3q25.2-27). ${ }^{10}$ At the present stage, the gene responsible for CCM1 (coding for KRIT1) has been identified, ${ }^{11}$ while the genes responsible for CCM2 and CCM3 remain unknown. ${ }^{10}$ The present study evaluated linkage in five non-Hispanic kindreds that participated in the International Familial Cavernous Angioma Study (IFCAS $)^{12,13}$ to assess the role of previously identified loci.

\section{Subjects}

Twenty-nine families were identified in kindreds collected from the IFCAS. ${ }^{12}$ These families were from Switzerland, Italy, United States, Japan and Germany. Neurological signs and symptoms included visual deficit, paresis, seizure, paresthesia and headache. Diagnoses were based on MRI or computed tomography (CT) in at least two affected family members and in some cases biopsy, surgical excision or autopsy. Asymptomatic subjects with no history of stroke, seizure disorder or focal neurological deficit were classified as unaffected. Index cases of each family were screened for CCM1 gene mutations, and 11 were identified. ${ }^{14}$ Of the remaining families, five were chosen for linkage analysis at the known CCM loci since they were large enough to yield potentially significant Lod scores and were not found to have CCM1 gene mutations. These families were from
Switzerland (IFCAS-1, IFCAS-4, IFCAS-31) and from the United States of Irish descent (IFCAS-35).

\section{Methods}

\section{A) Mutation detection}

Families were screened for mutations in the CCM1 gene using denaturing high performance liquid chromatography (DHPLC). After informed consent, blood samples were taken from each subject and DNA was extracted from peripheral blood by standard methods. Each of the 16 CCM1 coding exons was amplified by polymerase chain reaction (PCR) with intronic primers (Table 1). Polymerase chain reaction-amplified products were denatured by heating to $95^{\circ} \mathrm{C}$ for five minutes, followed by cooling to room temperature over a 45 minute period to enhance heteroduplex formation. The sequences of these fragments were analyzed using Wavemaker software package (Transgenomics, USA). Each variant found by DHPLC was re-amplified by PCR and directly sequenced on an ABI 3700 automated sequencer using BigDye chemistry, according to the manufacturer's recommended protocol (Applied Biosystems, Foster City, CA, USA).

\section{B) Linkage analysis and haplotyping}

Linkage was performed using highly informative di-, tri-, and tetranucleotide polymorphic markers retrieved either from the Cooperative Human Linkage Center (CHLC) (http://lpg.nci. nih.gov/CHLC/) or from the Centre d'Etude du Polymorphisme Humain (CEPH) (http://www.cephb.fr/). Primer sequences were obtained either from the CHLC or from the GDB ${ }^{\mathrm{TM}}$ Human Genome Database (http://www.gdb.org/). Each primer pair was amplified according to specific PCR conditions and labeled with 35S-dATP. Polymerase chain reaction-amplified products were transferred on $6 \%$ denaturing acrylamide gels and visualized on autoradiography film. Marker allele frequencies were obtained from the $\mathrm{CEPH}$ database and map distances between markers

Table 1: Primers for PCR amplification and sequencing of KRIT1 coding exons for CCM1 gene screening (all primers read 5' to 3').

\begin{tabular}{lll}
\hline $\begin{array}{l}\text { Exons } \\
4\end{array}$ & \multicolumn{1}{c}{ Forward primers (sense) } & \multicolumn{1}{c}{ Reverse primers (antisense) } \\
5 & TTGAGTAGTTGAACAGTAAAGATG & AAAATAATGGGCAGAGACCTAAA \\
6 & TATGCAGCTAGAGTTGAGAAAGAC & CTAGGGAACTACACTTCACATCAA \\
7 & TTTGCATTTATCAGTTTTATTAG & TGCCTTCCCTCCTCATT \\
8 & CAAGGTCACAGAGCTAGTCATCAC & ACCCAGGCCAGGACAACCTTA \\
9 & CACTTTCGAATGGCTACTTCTACC & ACTGTACCAGGCCTTCATGTTTAT \\
10 & AAACAAAGCTCTTAATGGGT & GACTACAATGCATACAAATTGC \\
11 & CATTTCAGATGATCTTTTTAGG & AGAACAGTCTTGAAAAGAAGGA \\
12 & ATTGGATGACATTTTCCCTT & TGTCATTACTTGTTATTCACTGCT \\
13 & AGCACATGAAGTTGAAGGAA & AGCCATCTAATCGTCTTTCC \\
14 & GAAGTGCAGACAGTTTAATACAAA & CCCAAAAAGGAATAATGAGG \\
15 & GCTTTTTCTTTTCCCATATT & CTCAACAGATTTTGTGCATTT \\
16 & CGTTACTGAAAGCCATTTGT & TAGCACAAGACCATGCATAA \\
17 & CAATGGTACATTTTCCTTTCA & CAGGACTATAAATTTAATCTACCTCTG \\
18 & CTGAACTATTATATTTAGAGCAGACA & AGGTTGGTACTGTTGTTTTAACT \\
19 & CCCAATGTCATGAATTTCC & CACAATAGTTTATGAAGTCCAAA
\end{tabular}




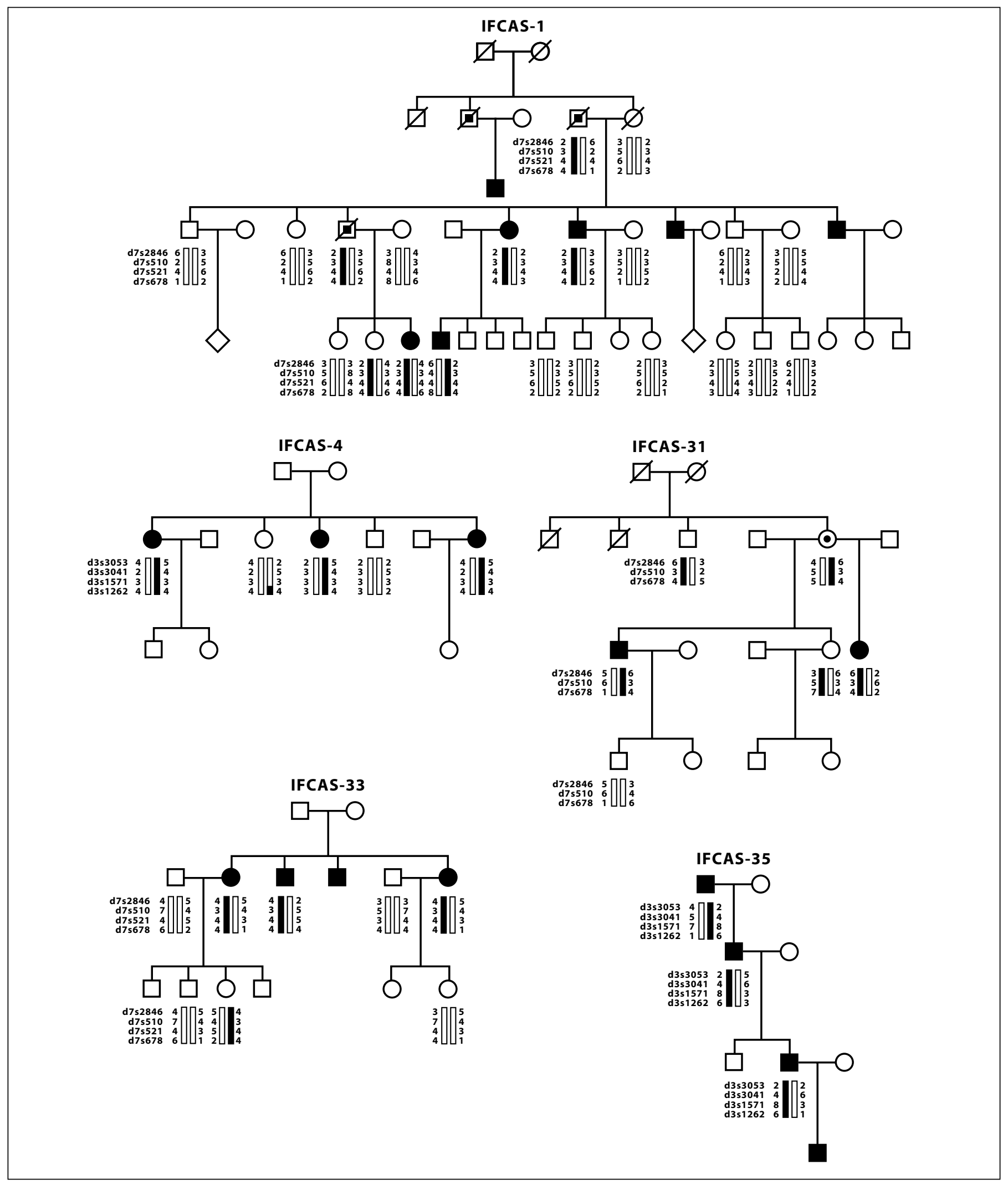

Figure 1: Haplotypes of IFCAS-1, IFCAS-31, IFCAS-33 (CCM2 locus) and IFCAS-4, IFCAS-35 (CCM3 locus). Black symbols indicate subjects considered affected based on MRI or pathological diagnosis. Open symbols indicate subjects considered unaffected based on clinical evaluation. Open symbols with black dots indicate obligate carriers. Crossed symbols indicate deceased subjects. 
were determined from the constructed linkage map of Marshfield (http://research.marshfieldclinic.org). For haplotyping of CCM1, we used markers D7S2410, D7S646, D7S1789, and D7S1813; for CCM2, markers D7S2846, D7S510, D7S521 and D7S678; for CCM3, markers D3S3053, D3S3041, D3S1571, and D3S1262. For linkage analysis of CCM1, we used markers D7S2410 D7S1813, and D7S646; for CCM2, D7S2846, D7S510, D7S667, and D7S678; for CCM3, D3S1571, D3S1754, D3S3041, and D3S3053. Linkage analysis was performed with the MLINK program of the FASTLINK v.3.0P analytical package ${ }^{15,16}$ using an autosomal dominant inheritance model with $90 \%$ non age-dependant penetrance and $0.1 \%$ phenocopy. This model had been used before in previous similar studies ${ }^{10,17}$ considering that precise epidemiological data is still lacking. Empirical $\mathrm{P}$ value was obtained using the SIMULATE program and the replicates were analyzed using MSIM program of the SLINK package. ${ }^{18,19}$ Ten thousand replicates were carried out, using the corresponding genetic model and marker information from linkage computation.

\section{RESULTS}

The families large enough to perform linkage analysis were IFCAS-1, IFCAS-4, IFCAS-31, IFCAS-33, and IFCAS-35. They were first screened for mutations in the CCM1 gene with the DHPLC method which has more than $90 \%$ sensitivity. ${ }^{20}$ None of the five families were found to have mutations in the CCM1 gene. Then we used highly polymorphic markers to perform haplotyping in each individual family for each known CCM loci (CCM1, CCM2, and CCM3). The segregation pattern of each marker in each family was established (Figure 1). For IFCAS-1, IFCAS-31 and IFCAS-33, haplotypes supported segregation of markers with the CCM2 locus but not with the CCM1 or CCM3 loci. For IFCAS-4 and IFCAS-35, haplotypes supported segregation of markers with the CCM3 locus but not with CCM1 or CCM2 loci. Then, we performed two-point linkage analysis in each family for each locus (Table 2). A maximum Lod score of 2.03 at $\theta=0(\mathrm{p}<0.0001)$ was obtained for IFCAS-1 with marker D7S678, $1.07 \mathrm{cM}$ telomeric from the point of highest Lod score reported by Craig et $\mathrm{al}^{10}$ at marker D7S521, therefore supporting linkage of the IFCAS-1 family to the CCM2 locus. We also performed multipoint linkage analysis in IFCAS-1 at the CCM2 locus with markers D7S510, D7S678, and D7S667 (Figure 2). Linkage was excluded for IFCAS-1 at the CCM1 locus and for IFCAS-35 at the CCM2 locus. Otherwise, none of the other families showed significant Lod scores that could allow definite exclusion or confirmation of linkage.

\section{Discussion}

In the present study, we report linkage of one family (IFCAS1) to the CCM2 locus. IFCAS-1 was tested for mutations in the CCM1 gene, and none was found. Additionally, linkage was excluded at the CCM1 locus for this family, while it was confirmed at the CCM2 locus with a positive Lod score and supportive empirical $\mathrm{p}$ value. As for the other families, they are unlikely to be related to the CCM1 locus, since they have been screened for mutations in the CCM1 gene with DHPLC, which provides more than $90 \%$ sensitivity. ${ }^{20}$ Additionally, haplotypes did not suggest linkage to the CCM1 locus. For IFCAS-31 and

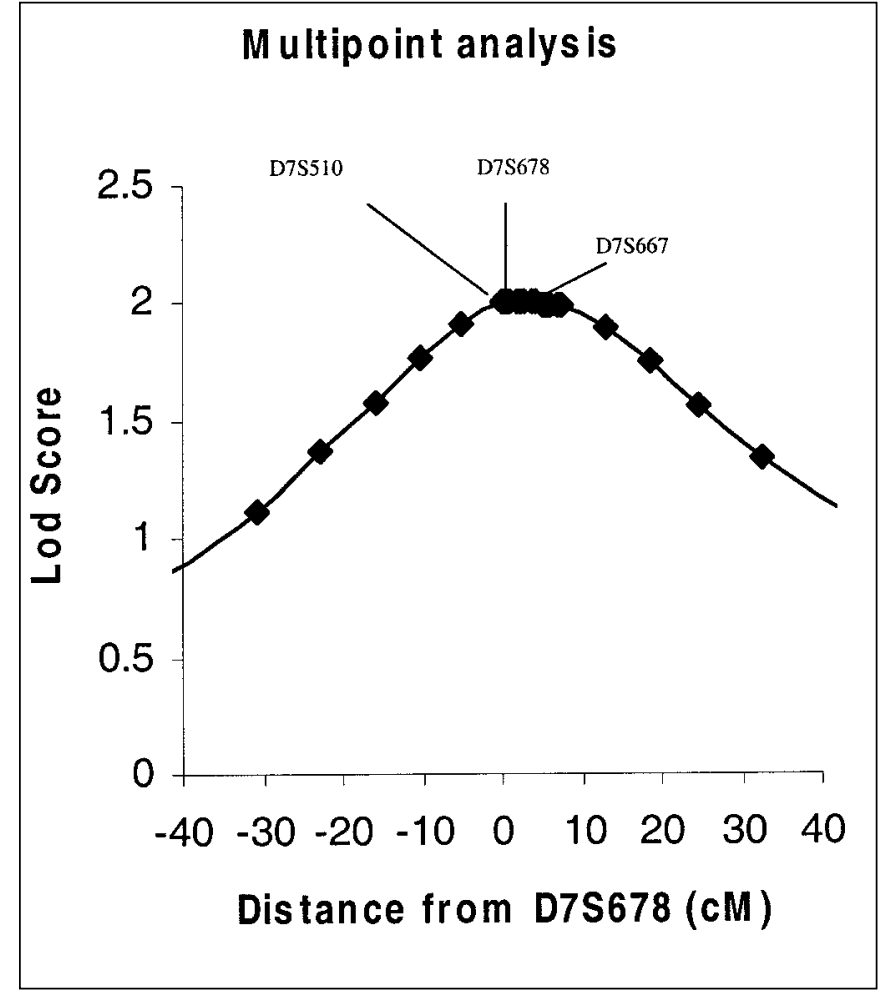

Figure 2: Multipoint analysis of linkage performed for CCM2 with IFCAS-1 using markers D7S510, D7S678 and D7S667. The highest Lod score (2.01) is 1.07 cM telomeric from marker D7S521.

IFCAS-33, haplotypes supported linkage to the CCM2 locus, while for IFCAS-4 and IFCAS-35 haplotypes supported linkage to the CCM3 locus. Obviously, these cannot be considered as definitive proof of linkage, since the Lod scores were not significant because of the small sample size in each family.

Previous studies have shown evidence of genetic heterogeneity in CCM. Laberge et $\mathrm{al}^{21}$ showed that in the French population, the proportion of families linked to the CCM1 locus was of $65 \%$. Gunel et $\mathrm{al}^{9}$ reported two non-Hispanic families showing no evidence of linkage to the CCM1 locus. Craig et al ${ }^{10}$ reported definite linkage in three families to the CCM1 locus, in four families to the CCM2 locus, and in two families to the CCM3 locus. Our study thus provides evidence supporting genetic heterogeneity in familial CCM, as well as being the first report replicating the existence of the CCM2 locus and suggesting that other families may also be linked to the CCM2 and CCM3 loci. The recent description of the CCM1 gene ${ }^{11}$ will assist greatly in the identification of other CCM genes that might have sequence homology to CCM1 or that might be acting on the same biochemical pathway. We are presently carrying out candidate gene screening for the CCM2 and CCM3 loci, which should allow us to identify the gene responsible for these disorders. As other genes are identified, we will need to investigate further the pathogenesis of cavernous angioma formation to understand why, for example, while all blood vessels harbor inherited CCM mutations, only a small number of lesions develop. 
Table 2: Two-point Lod scores for ranges of theta obtained for each family at loci CCM1, CCM2 and CCM3.

\begin{tabular}{|c|c|c|c|c|c|c|c|c|}
\hline Theta & & 0.00 & 0.01 & 0.05 & 0.10 & 0.20 & 0.30 & 0.40 \\
\hline \multicolumn{9}{|l|}{ IFCAS-1 } \\
\hline \multirow[t]{3}{*}{ CCM1 } & D7S2410 & -5.18 & -2.52 & -1.13 & -0.58 & -0.16 & -0.04 & -0.01 \\
\hline & D7S1813 & -4.19 & -1.44 & -0.61 & -0.24 & 0.06 & 0.11 & 0.05 \\
\hline & D7S646 & -3.65 & -0.95 & -0.25 & 0.01 & 0.16 & 0.13 & 0.05 \\
\hline \multirow[t]{4}{*}{$\mathrm{CCM} 2$} & D7S2846 & 0.95 & 0.96 & 0.94 & 0.88 & 0.66 & 0.37 & 0.10 \\
\hline & D7S510 & 1.21 & 1.21 & 1.18 & 1.10 & 0.83 & 0.48 & 0.13 \\
\hline & D7S667 & 1.13 & 1.13 & 1.08 & 0.99 & 0.70 & 0.37 & 0.09 \\
\hline & D7S678 & 2.03 & 2.02 & 1.94 & 1.79 & 1.38 & 0.85 & 0.28 \\
\hline \multirow[t]{4}{*}{ CCM3 } & D3S1571 & 0.35 & 0.37 & 0.40 & 0.39 & 0.31 & 0.18 & 0.05 \\
\hline & D3S1754 & 0.55 & 0.57 & 0.60 & 0.59 & 0.49 & 0.32 & 0.12 \\
\hline & D3S3041 & 0.52 & 0.54 & 0.56 & 0.55 & 0.45 & 0.28 & 0.10 \\
\hline & D3S3053 & -1.49 & -0.41 & 0.29 & 0.53 & 0.59 & 0.41 & 0.15 \\
\hline \multicolumn{9}{|l|}{ IFCAS-4 } \\
\hline \multirow[t]{3}{*}{ CCM1 } & D7S2410 & 0.87 & 0.85 & 0.77 & 0.66 & 0.45 & 0.24 & 0.07 \\
\hline & D7S1813 & 0.04 & 0.05 & 0.09 & 0.11 & 0.10 & 0.06 & 0.02 \\
\hline & D7S646 & -0.03 & -0.03 & -0.03 & -0.03 & -0.02 & -0.01 & 0.00 \\
\hline \multirow[t]{4}{*}{ CCM2 } & D7S2846 & -3.84 & -1.85 & -1.06 & -0.69 & -0.31 & -0.12 & -0.03 \\
\hline & D7S510 & -0.40 & -0.39 & -0.35 & -0.28 & -0.16 & -0.07 & -0.02 \\
\hline & D7S667 & -0.47 & -0.46 & -0.40 & -0.32 & -0.18 & -0.08 & -0.02 \\
\hline & D7S678 & -0.30 & -0.29 & -0.25 & -0.20 & -0.11 & -0.05 & -0.01 \\
\hline \multirow[t]{4}{*}{ CCM3 } & D3S1571 & -0.03 & -0.03 & -0.02 & -0.02 & -0.01 & -0.01 & 0.00 \\
\hline & D3S1754 & 0.82 & 0.80 & 0.72 & 0.61 & 0.40 & 0.21 & 0.06 \\
\hline & D3S3041 & 0.82 & 0.80 & 0.72 & 0.61 & 0.40 & 0.21 & 0.06 \\
\hline & D3S3053 & 0.82 & 0.80 & 0.72 & 0.61 & 0.40 & 0.21 & 0.06 \\
\hline \multicolumn{9}{|c|}{ IFCAS-33 } \\
\hline \multirow[t]{3}{*}{ CCM1 } & D7S2410 & 0.19 & 0.19 & 0.16 & 0.13 & 0.08 & 0.04 & 0.01 \\
\hline & D7S1813 & -0.69 & -0.60 & -0.37 & -0.22 & -0.08 & -0.02 & 0.00 \\
\hline & D7S646 & 0.30 & 0.30 & 0.27 & 0.24 & 0.17 & 0.09 & 0.03 \\
\hline \multirow[t]{4}{*}{$\mathrm{CCM} 2$} & D7S2846 & 0.33 & 0.31 & 0.26 & 0.20 & 0.10 & 0.04 & 0.01 \\
\hline & D7S510 & 0.30 & 0.29 & 0.24 & 0.18 & 0.09 & 0.03 & 0.00 \\
\hline & D7S667 & 0.48 & 0.47 & 0.42 & 0.36 & 0.24 & 0.12 & 0.03 \\
\hline & D7S678 & 0.20 & 0.19 & 0.15 & 0.11 & 0.04 & 0.01 & 0.00 \\
\hline \multirow[t]{4}{*}{ CCM3 } & D3S1571 & -0.73 & -0.63 & -0.39 & -0.23 & -0.08 & -0.02 & 0.00 \\
\hline & D3S1754 & -1.01 & -0.85 & -0.52 & -0.32 & -0.13 & -0.05 & -0.01 \\
\hline & D3S3041 & -1.01 & -0.85 & -0.52 & -0.32 & -0.13 & -0.05 & -0.01 \\
\hline & D3S3053 & -0.30 & -0.28 & -0.22 & -0.17 & -0.09 & -0.04 & -0.01 \\
\hline
\end{tabular}


Table 2: Two-point Lod scores for ranges of theta obtained for each family at loci CCM1, CCM2 and CCM3 continued ...

\begin{tabular}{|c|c|c|c|c|c|c|c|c|}
\hline \multicolumn{9}{|c|}{ IFCAS-31 } \\
\hline \multirow[t]{3}{*}{ CCM1 } & D7S2410 & -2.91 & -0.92 & -0.30 & -0.08 & 0.05 & 0.07 & 0.05 \\
\hline & D7S1813 & -1.37 & -1.29 & -1.03 & -0.78 & -0.43 & -0.22 & -0.09 \\
\hline & D7S646 & 0.35 & 0.34 & 0.31 & 0.28 & 0.21 & 0.14 & 0.07 \\
\hline \multirow[t]{4}{*}{ CCM2 } & D7S2846 & -0.80 & -0.72 & -0.46 & -0.25 & -0.03 & 0.05 & 0.05 \\
\hline & D7S510 & 0.38 & 0.38 & 0.36 & 0.33 & 0.26 & 0.18 & 0.08 \\
\hline & D7S667 & -0.32 & -0.27 & -0.15 & -0.06 & 0.04 & 0.07 & 0.05 \\
\hline & D7S678 & -0.35 & -0.32 & -0.21 & -0.12 & 0.00 & 0.05 & 0.05 \\
\hline \multirow[t]{4}{*}{ CCM3 } & D3S1571 & -3.42 & -1.41 & -0.71 & -0.42 & -0.16 & -0.04 & 0.01 \\
\hline & D3S1754 & -2.36 & -0.94 & -0.32 & -0.11 & 0.03 & 0.06 & 0.04 \\
\hline & D3S3041 & -0.02 & -0.01 & 0.03 & 0.06 & 0.09 & 0.09 & 0.06 \\
\hline & D3S3053 & 0.10 & 0.10 & 0.08 & 0.07 & 0.04 & 0.02 & 0.00 \\
\hline \multicolumn{9}{|c|}{ IFCAS-35 } \\
\hline \multirow[t]{3}{*}{ CCM1 } & D7S2410 & 0.00 & 0.00 & 0.00 & 0.00 & 0.00 & 0.00 & 0.00 \\
\hline & D7S1813 & 0.30 & 0.30 & 0.28 & 0.26 & 0.20 & 0.15 & 0.08 \\
\hline & D7S646 & 0.30 & 0.30 & 0.28 & 0.26 & 0.20 & 0.15 & 0.08 \\
\hline \multirow[t]{4}{*}{$\mathrm{CCM} 2$} & D7S2846 & 0.00 & 0.00 & 0.00 & 0.00 & 0.00 & 0.00 & 0.00 \\
\hline & D7S510 & -3.45 & -1.69 & -1.00 & -0.70 & -0.40 & -0.22 & -0.10 \\
\hline & D7S667 & 0.00 & 0.00 & 0.00 & 0.00 & 0.00 & 0.00 & 0.00 \\
\hline & D7S678 & -3.45 & -1.69 & -1.00 & -0.70 & -0.40 & -0.22 & -0.10 \\
\hline \multirow[t]{4}{*}{ CCM3 } & D3S1571 & 0.18 & 0.18 & 0.16 & 0.15 & 0.12 & 0.08 & 0.04 \\
\hline & D3S1754 & 0.00 & 0.00 & 0.00 & 0.00 & 0.00 & 0.00 & 0.00 \\
\hline & D3S3041 & -0.18 & -0.17 & -0.15 & -0.13 & -0.10 & -0.06 & -0.03 \\
\hline & D3S3053 & 0.30 & 0.30 & 0.28 & 0.26 & 0.20 & 0.15 & 0.08 \\
\hline
\end{tabular}

\section{ACKNOWLEDGEMENT}

We thank the families involved in these studies and the physicians who referred them to us. AMS was supported by the Schweizerischer Nationalfonds (Swiss National Research Foundation), the Kommission zur Förderung des akademischen Nachwuchses des Kt.Zürichs and the Julius Klaus-Stiftung. GAR is supported by the Canadian Institute of Health Research.

\section{REFERENCES}

1. Otten P, Pizzolato GP, Rilliet B, Berney J. 131 cases of cavernous angioma (cavernomas) of the CNS, discovered by retrospective analysis of 24,535 autopsies. Neurochirurgie 1989;35:82-83.

2. De Curling O, Kelly DL, Elster AD, Craven TE. An analysis of the natural history of cavernous angiomas. J Neurosurg 1991;75:702-708.

3. Maraire N, Awad IA. Intracranial cavernous malformations: lesion behavior and management strategies. Neurosurgery 1995;37:591605.

4. Siegel AM, Roberts DW, Harbaugh RI, Williamson PD. Pure lesionectomy versus tailored epilepsy surgery in treatment of cavernous angioma presenting with epilepsy. Neurosurg Rev 2000;23:80-83.

5. Russel DS, Rubenstein LJ. Pathology of tumors of the nervous system. Baltimore, MD: Williams and Wilkins, 1989:730-736.

6. Perl J, Ross J. Diagnostic imaging of cavernous malformations. In: Awad IA, Barrow D, (Eds.) Cavernous malformations. Park
Ridge, IL: American Association of Neurological Surgeons Press, 1993:37-48.

7. Rigamonti D, Hadley MN, Drayer BP, et al. Cerebral cavernous malformations. New Engl J Med 1988;319:343-347.

8. Gunel M, Awad IA, Finberg K, et al. A founder mutation as a cause of cerebral cavernous malformation in Hispanic Americans. New Engl J Med 1996;334:946-951.

9. Gunel M, Awad IA, Finberg K, et al. Genetic heterogeneity of inherited cerebral cavernous malformation. Neurosurgery 1996;38:1265-1271.

10. Craig HD, Gunel M, Cepeda O, et al. Multilocus linkage identifies two new loci for a mendelian form of stroke, cerebral cavernous malformation, at 7p15-13 and 3q25.2-27. Hum Mol Genet 1998; 7:1851-1858.

11. Laberge-le Couteulx S, Jung HH, Labauge P, et al. Truncating mutations in CCM1, encoding KRIT1, cause hereditary cavernous angiomas. Nat Genet 1999;23:189-193.

12. Siegel AM, Andermann E, Badhwar A, et al. Anticipation in familial cavernous angioma: a study of 52 families from International Familial Cavernous Angioma Study. IFCAS Group. Lancet 1998;352:1676-1677.

13. Verlaan DJ, Davenport WJ, Stefan H, et al. Literature review and identification of new mutations in the Krit1 gene. Neurology 2002;58:853-857.

14. Davenport WJ, Siegel AM, Dichgans J, et al. CCM1 gene mutations in families segregating cerebral cavernous malformations. Neurology 2001;56:540-543. 
15. Cottingham RWJ, Idury RM, Schaffer AA. Faster sequential genetic linkage computation. Am J Hum Genet 1993;53:252-263.

16. Schaffer AA, Gupta SK, Schriram K, Cottingham RWJ. Avoiding recomputation in linkage analysis. Hum Hered 1994;44:225-237.

17. Dubovsky J, Zabramski JM, Kurth J, et al. A gene responsible for cavernous malformations of the brain maps to chromosome $7 \mathrm{q}$. Hum Mol Genet 1995;4:453-458.

18. Ott J. Computer-simulation methods in human linkage analysis. Proc Natl Acad Sci USA 1989;86:4175-4178.
19. Weeks DE, Lathrop GM. SLINK: a general simulation program for linkage analysis. Am J Hum Genet 1990;(Suppl 47):A204.

20. O’Donovan MC, Oefner PJ, Roberts SC, et al. Blind analysis of denaturing high-performance liquid chromatography as a tool for mutation detection. Genomics 1998;52:44-49.

21. Laberge S, Labauge P, Marechal E, et al. Genetic heterogeneity and absence of founder effect in a series of 36 French cerebral cavernous angiomas families. Eur J Hum Genet 1999;7:499-504. 